\title{
Variability of apparent ileal amino acid digestibility in high-protein wheat samples for growing-finishing pigs*
}

\author{
M.Z. Fan ${ }^{1}$, W.C. Sauer ${ }^{2}$ and S. $\mathrm{Li}^{2}$ \\ 'Department of Animal and Poultry Science. University of Guelph \\ Guelph, Ontario, Canada NIG 2W1 \\ 'Department of Agricultural, Food and Nutritional Science, \\ University of Alberta \\ Edmonton, Alberta, Canada T6G 2P5
}

(Reccived 31 July 2000; accepted 22 January 2001)

\begin{abstract}
An experiment was conducted to investigate factors responsible for the variability of apparent ileal digestibility values of amino acids (AA) in high-protein wheat samples. Six barrows, average initial body weight $30.5 \mathrm{~kg}$, fitted with a simple T-cannula at the distal ilcum, were fed six diets according to a $6 \times 6$ Latin square design. The six diets included $970 \mathrm{~g} \mathrm{~kg}^{-1}$ of different samples of wheat. Chromic oxide was used as the digestibility marker. The barrows were fed twice daily, at 08:00 and 20:00 h. The dietary allowance was 1,600 $\mathrm{g} \mathrm{d}^{-1}$. Each experimental period consisted of $8 \mathrm{~d}$. Ilcal digesta were collected for a total of $24 \mathrm{~h}$, at 2-h intervals, from 08:00 on $\mathrm{d} 6$ to $08: 00 \mathrm{~h}$ on $\mathrm{d} 8$. There were differences $(\mathbf{P}<0.05)$ in the apparent ileal digestibility values of all amino acids (AA) among the wheat samples. Of the indispensable (+semi-) amino acids (AA), within each sample, the digestibility values of lysine and threonine, the first- and second-limiting AA, were lowest and ranged from 59.0 to $70.3(P<0.05)$ and 64.2 to $73.0 \%(P<0.05)$, respectively. With the exception of arginine and tyrosine, the digestibility values of the other indispensable (+semi-) AA, were negatively correlated $(\mathrm{P}<0.05)$ with neutral-detergent fibre (NDF) content, whereas differences in dictary AA contents did not affect the variability of the ileal AA digestibility values in the wheat samples. In conclusion, measured with the ileal analysis method, there was considerable variation in the digestibility values of AA in high-protein wheat samples. Differences in NDF content were, in part, responsible for the variation. Furthermore, the relatively low digestibility values of lysine, threonine and tryptophan further accentuate the limitation of these AA in proteins from wheat.
\end{abstract}

\footnotetext{
* Supported by the Alberta Agricultural Research Institute, Halchemix Canada Inc., Toronto, ON and Heartland Lysine Inc., Chicago, IL

1 Corresponding author
} 
KEY WORDS: neutral-detergent fibre, amino acids, ileal digestibility, wheat, pigs

\section{INTRODUCTION}

Wheat is a major ingredient in swine diets in Western Canada. This cereal grain, together with barley, usually supplies approximately half of the protein in diets for growing and finishing pigs. There is a considerable variation in the crude protein (CP) and amino acid (AA) contents in wheat; the CP content can range from 60 to $202 \mathrm{~g} \mathrm{~kg}^{-1}$ dry matter (Suleiman, 1987; Simmonds, 1989). Furthermore, the nutritive value of protein in wheat is not only determined by its total content in AA, but also by their digestibility values with particular reference to the limiting AA.

The ileal rather than faecal analysis method should be used to determine AA digestibility values in feedstuffs for pigs because of the modifying action of the

microflora in the large intestine (e.g., Żebrowska, 1973). From data compiled from the literature, there was considerable variation in the apparent ileal digestibility values of AA among different wheat samples (e.g., Sauer and Ozimek, 1986).

Inherent factors, such as differences in neutral-detergent fibre (NDF) content, were found to be partly responsible for the variation in ileal digestibility values of AA in wheat samples (e.g., Taverner and Farrell, 1981). In addition, the variability of ileal AA digestibility values in wheat samples may also result from methodological approaches, such as differences in AA contents in assay diets and the use of different methods of determination, as reported by Fan et al. (1994) and Fan and Sauer (1995a,b). Accurate information on factors affecting AA digestibility values is of importance for cconomical formulation and/or AA supplementation to wheat-based diets for pigs and for plant breeders to improve wheat protein quality.

The objectives of this study were to investigate the variability of apparent ileal digestibility values of AA in high-protein wheat samples and to examine how inherent and methodological factors are responsible for the variation. Six samples of high-protein wheat, of which the production has increased during the last decade in Western Canada as a premium is paid if the CP content exceeds $130 \mathrm{~g} \mathrm{~kg}^{-1}$, were examined.

\section{MATERIAL AND METHODS}

Animal trial procedures

Six barrows (Lacombe x Yorkshire), average initial body weight $30.5 \mathrm{~kg}$, were surgically fitted with a simple T-cannula approximately $5 \mathrm{~cm}$ anterior to the ileocaecal sphincter according to procedures adapted from Sauer et al. (1983). The 
cannulas were modified according to De Lange et al. (1989). After surgery, the barrows were housed individually in stainless steel metabolic crates in a temperature-controlled barn $\left(20-22^{\circ} \mathrm{C}\right)$. During a 14 -d recovery period, the barrows were fed a $160 \mathrm{~g} \mathrm{CP} \mathrm{kg}^{-1}$ grower diet (Sauer et al., 1983). Sauer (1976) and Sauer et al. (1983) previously presented a detailed description of pre- and post-operative care. After recovery, the barrows were fed one of six experimental diets according to a 6 x 6 Latin square design. They were fed 800 g twice daily, at 08:00 and 20:00 h. Water was freely available from a low-pressure drinking nipple. At the conclusion of the experiment, the barrows, average final body weight of $61.2 \mathrm{~kg}$, were electrically stunned before killing, bled out and dissected to determine whether cannulation had caused intestinal abnormalities.

Six samples of wheat with high protein contents ( 149.4 to $175.6 \mathrm{~g} \mathrm{~kg}^{-1}$, as fed) were obtained for these studies: c.v. Katepwa from Alberta Wheat Pool, Calgary, Alberta; c.v. Katepwa from Alberta United Grain Growers, Edmonton, Alberta; c.v. Katepwa from Saskatchewan Wheat Pool, Saskatoon, Saskatchewan; c.v. Neepawa from Saskatchewan Wheat Pool, Saskatoon, Saskatchewan; c.v. Kyle from Saskatchewan Wheat Pool, Saskatoon, Saskatchewan; c.v. Columbus from Saskatchewan Wheat Pool, Saskatoon, Saskatchewan. Wheat supplied the sole source of dietary protein (Table 1). Vitamins and minerals were supplemented according to NRC (1988) standards. Chromic oxide ( $3 \mathrm{~g} \mathrm{~kg}^{-1}$ diet) was included in the diets as the digestibility marker. Wheat was ground through a $4.8-\mathrm{mm}$ mesh screen prior to diet incorporation.

Each experimental period comprised of 8 days. Ileal digesta were collected for a total of $24 \mathrm{~h}$ : from $08: 00$ to $10: 00 \mathrm{~h}$ on $\mathrm{d} 6$, every other $2 \mathrm{~h}$ thereafter until $08: 00 \mathrm{~h}$ on $\mathrm{d} 7$, and from 10:00 to $12: 00 \mathrm{~h}$ on $\mathrm{d} 7$, and every other $2 \mathrm{~h}$ thereafter until $08: 00 \mathrm{~h}$ on $\mathrm{d} 8$. Ileal digesta were collected in soft plastic tubing (length, $25 \mathrm{~cm}$; internal diameter, $2.5 \mathrm{~cm}$ ) which was attached to the barrel of the cannula with Velcro tape. The tubing contained $10 \mathrm{~mL}$ of formic acid solution $(10 \%, \mathrm{v} / \mathrm{v})$ to minimize further microbial activity. The tubing was removed and replaced as soon as it was partially filled with digesta. Digesta samples were immediately frozen at $-20^{\circ} \mathrm{C}$ following collection.

The experimental proposal, surgical procedures and procedures for care and treatment of the barrows were reviewed and approved by the Faculty of Agriculture and Forestry Animal Care Committee of the University of Alberta. The barrows used in this experiment were cared for in accordance with the guidelines established by the CCAC (1980).

\section{Chemical analyses}

After the conclusion of the animal trial, the digesta were freeze-dried, pooled within barrow and period for the same dietary treatment, ground through a $0.8-\mathrm{mm}$ 
TABLE 1

Formulation of the experimental diets, $\mathrm{g} \mathrm{kg}^{-1}$ air dry weight

\begin{tabular}{lr}
\hline Ingredients & $\mathrm{g} \mathrm{kg}^{-1}$ \\
\hline Wheat & 970 \\
Calcium carbonate & 11 \\
Dicalcium phosphatc $^{1}$ & 8 \\
Trace-mineralized salt $^{2}$ & 5 \\
Vitamin premix $^{3}$ & 2 \\
Mineral premix $^{4}$ & 1 \\
Chromic oxide $^{5}$ & 3 \\
\hline
\end{tabular}

1 the six wheat diets (diets 1 to 6) contained the following wheat samples: diet 1, c.v. Katepwa from Alberta Wheat Pool, Calgary, Alberta; diet 2, c.v. Katepwa from Alberta United Grain Growers, Edmonton, Alberta; diet 3, c.v. Katepwa from Saskatchewan Wheat Pool, Saskatoon, Saskatchewan; diet 4, c.v. Necpawa from Saskatchewan Wheat Pool, Saskatoon. Saskatchewan; diet 5, c.v. Kyle from Saskatchewan Wheat Pool, Saskatoon, Saskatchewan; diet 6, c.v. Columbus from Saskatchewan Wheat Pool, Saskatoon, Saskatchewan

2 supplied by Windsor Salt, Toronto, Canada. Composition ( $\mathrm{g} \mathrm{kg}^{-1} \mathrm{salt}$ ): $\mathrm{NaCl}, 965 ; \mathrm{ZnO}, 4.0 ; \mathrm{FcCO}_{3}$, 1.6; $\mathrm{MnO}, 1.2 ; \mathrm{CuO}, 0.33 ; \mathrm{Ca}\left(\mathrm{IO}_{3}\right)_{2}, 0.07 ; \mathrm{CaO}, 0.04$

${ }^{3}$ the vitamin premix supplied the following vitamins ( $\mathrm{mg} \mathrm{kg}^{-1}$ diet): retinyl palmitate, 5.2 ; cholccalciferol, 0.38 ; all-rac- $\alpha$-tocopheryl acetate, 44.0 ; menadione, 3.0 ; riboflavin, 2.2 ; niacin, 12.0 ; d-pantothenic acid, 11.0 ; vitamin $B_{12}, 0.012$; choline, 550 ; thiamine, 1.1 ; pyridoxine, 1.1; d-biotin $0.1 ;$ folic acid, 0.6

${ }^{4}$ the trace-mineral premix supplied the following minerals ( $\mathrm{mg} \mathrm{kg}{ }^{-1}$ diet): $\mathrm{FeSO}_{4} \mathrm{H}_{2} \mathrm{O}, 152.0 ; \mathrm{ZnCO}_{3}$, $95.9 ; \mathrm{MnSO}_{4} \mathrm{H}_{2} \mathrm{O}, 6.2 ; \mathrm{CuSO}_{4} 5 \mathrm{H}_{2} \mathrm{O}, 11.8 ; \mathrm{KI}, 0.60 ; \mathrm{Na}_{2} \mathrm{SeO}_{3}, 0.30$

$s$ Fisher Scientific, Fair Lawn, NJ

mesh screen in a Wiley mill and mixed before analyses. Samples of wheat and diets were ground similarly.

Analyses for dry matter, $\mathrm{CP}$ and ether extract were carried out according to AOAC (1990) methods. Analysis for NDF was carricd out according to principles outlined by Gocring and Van Soest (1970). Chromic oxide was determined according to the procedure of Fenton and Fenton (1979).

For AA analyses, with the exception of the sulphur-containing AA and tryptophan, the samples were hydrolysed with $6 \mathrm{M} \mathrm{HCl}$ at $110^{\circ} \mathrm{C}$ for $24 \mathrm{~h}$. The AA were analysed by ion-exchange chromatography using an automatic AA analyzer according to procedures adapted from Mason et al. (1980). Methionine and cysteine were determined as methionine sulphone and cysteic acid after oxidation with performic acid; the oxidation process was carried out according to AOAC (1990). The oxidised samples were then hydrolysed and analysed in the same manner as the samples that were not oxidised. Tryptophan analysis was carried out according to the procedure described by Jones et al. (1981). 


\section{Calculations and statistical analyses}

The apparent ileal digestibility values of $\mathrm{CP}$ and $\mathrm{AA}$ in the wheat samples were determined with the direct method using equation (1):

$$
D_{D}=100 \%-\left[\left(I_{D} \times A_{F}\right) /\left(I_{F} \times A_{D}\right)\right] \times 100 \%
$$

Where $D_{D}$ is apparent digestibility of a nutrient in the diet $(\%) ; I_{D}$ is the marker concentration in the diet $(\%) ; A_{F}$ is the concentration of a nutrient in ileal digesta $(\%) ; I_{F}$ is the marker concentration in ileal digesta (percentage); $A_{D}$ is the concentration of a nutrient in the diet $(\%)$.

Three different pigs went off feed during the experiment, which resulted in three missing values; one during the first, third and fourth experimental period, respectively. The digestibility values were first subjected to least square analyses of variance (LSAV) for a $6 \times 6$ Latin square design. Periods and barrows were the controlled factors in the $6 \times 6$ Latin square design. Where appropriate, least square means for treatments were compared using the probability of difference (PDIFF) procedure (SAS, 1988). The LSAV and PDIFF were carried out using the General Linear Model (GLM) Procedures of SAS (1988) according to the principles described by Steel and Torrie (1980). Pearson partial correlation analyses were conducted to determine the relationships between the apparent ileal digestibility values of $\mathrm{CP}$ and $\mathrm{AA}$ and the NDF content in the wheat samples and the dietary levels of CP and AA using the GLM procedure of SAS (1988). Variation contributed by barrows and periods was removed by creating five dummy variables for barrows and periods, respectively, and obtaining partial correlation coefficients when the dummy variables were forced into analyses (Draper and Smith, 1981).

\section{RESULTS AND DISCUSSION}

The pigs, with the exception of the instances mentioned previously, remained healthy and consumed their meal allowances throughout the experiment. Postmortem examinations, carried out at the conclusion of the experiment, revealed no intestinal adhesions or other abnormalities.

The chemical composition of the wheat samples and diets is shown in Tables 2 and 3, respectively. The analyzed values of $\mathrm{CP}$ and $\mathrm{AA}$ in the diets were close to the calculated values that were based on the analyzed values in the different wheat samples. The NDF content in wheat ranged from 117 to $176 \mathrm{~g} \mathrm{~kg}^{-1}$ (Table 2). The dietary NDF content was calculated from the values determined in the wheat samples. The contents of CP, lysine and threonine in wheat in this study ranged from 170 to $199,4.3$ to 5.0 and 4.9 to $5.8 \mathrm{~g} \mathrm{~kg}^{-1}$, respectively. These values, and also those of the other AA, were considerably higher than those reported by Sauer et al. 
TABLE 2

Dry matter, ether extract, neutral-detergent fibre, crude protein and amino acid contents ${ }^{\downarrow}$ in the wheat samples, $\mathrm{g} \mathrm{kg}^{-1}$

\begin{tabular}{|c|c|c|c|c|c|c|}
\hline & \multicolumn{6}{|c|}{ Wheat samples ${ }^{2}$} \\
\hline & Wl & W2 & W3 & W4 & W5 & W6 \\
\hline Dry matter & 893 & 899 & 904 & 899 & 905 & 912 \\
\hline Ether extract & 10 & 13 & 12 & 16 & 13 & 14 \\
\hline Neutral-detergent fibre & 122 & 149 & 135 & 134 & 117 & 176 \\
\hline Crude protein & 192 & 183 & 170 & 177 & 199 & 191 \\
\hline \multicolumn{7}{|l|}{ Amino acids } \\
\hline \multicolumn{7}{|l|}{ Indispensable (+seni-) } \\
\hline Arg & 10.0 & 9.0 & 8.6 & 9.8 & 10.2 & 10.0 \\
\hline Cys & 4.6 & 4.1 & 4.0 & 4.3 & 4.4 & 4.4 \\
\hline His & 4.5 & 4.0 & 3.1 & 4.0 & 3.9 & 4.3 \\
\hline He & 6.4 & 5.7 & 5.1 & 5.7 & 6.5 & 5.8 \\
\hline Leu & 13.0 & 11.8 & 10.7 & 11.7 & 13.3 & 12.2 \\
\hline Lys & 5.0 & 4.8 & 4.3 & 4.9 & 4.6 & 4.8 \\
\hline Met & 3.2 & 2.9 & 3.0 & 3.0 & 3.3 & 3.2 \\
\hline Phe & 8.8 & 7.6 & 7.1 & 7.2 & 8.7 & 7.8 \\
\hline Thr & 5.8 & 5.3 & 4.9 & 5.3 & 5.5 & 5.4 \\
\hline Trp & 2.0 & 2.1 & 2.2 & 2.3 & 2.2 & 2.1 \\
\hline Tyr & 3.5 & 2.9 & 2.4 & 2.2 & 4.3 & 2.4 \\
\hline Val & 8.1 & 7.2 & 6.6 & 7.5 & 8.0 & 7.3 \\
\hline \multicolumn{7}{|l|}{ Dispensable } \\
\hline $\mathrm{Ala}$ & 6.4 & 5.8 & 5.6 & 6.0 & 6.6 & 6.4 \\
\hline Asp & 9.3 & 8.6 & 8.6 & 9.8 & 10.2 & 10.0 \\
\hline Glu & 64.7 & 58.0 & 55.7 & 55.7 & 67.4 & 65.1 \\
\hline Gly & 7.6 & 6.9 & 6.5 & 7.0 & 7.1 & 7.5 \\
\hline Pro & 21.3 & 18.9 & 18.7 & 18.2 & 21.2 & 21.3 \\
\hline Ser & 9.1 & 8.3 & 7.6 & 8.1 & 9.1 & 8.9 \\
\hline
\end{tabular}

1 dry matter basis

2 refer to footnote 1 to Table 1

(1981) and the average values compiled by NRC (1988) for wheat. However, the $\mathrm{CP}$ content was within the range of values, 123 to $202 \mathrm{~g} \mathrm{~kg}^{-1}$, with an average of $161 \mathrm{~g} \mathrm{~kg}^{-1}$ reported for 161 samples of spring wheat grown in Alberta (Suleiman, 1987). Like in many other plant seeds, the rate of protein synthesis and accumulation in wheat is genetically controlled and affected by many environmental factors (c.g., Byers et al., 1978; Simmonds, 1989). Based on the original classification by Osborne (1909), wheat proteins can be distinguished into albumins, globulins, prolamins (gliadins) and glutenins depending on their solubility in water, saline 
TABLE 3

Dry matter, ether extract, neutral-detergent fibre, crude protein and amino acid contents' in the experimental diets, $\mathrm{g} \mathrm{kg}^{-1}$

\begin{tabular}{|c|c|c|c|c|c|c|}
\hline & \multicolumn{6}{|c|}{ Experimental dicts ${ }^{2}$} \\
\hline & 1 & 2 & 3 & 4 & 5 & 6 \\
\hline Dry matter & 909 & 904 & 900 & 904 & 905 & 905 \\
\hline Ether extract & 10 & 12 & 11 & 14 & 12 & 13 \\
\hline Neutral-detergent fibre & 115 & 144 & 132 & 129 & 114 & 172 \\
\hline Crude protein & 182 & 174 & 166 & 171 & 194 & 185 \\
\hline \multicolumn{7}{|l|}{ Amino acids } \\
\hline \multicolumn{7}{|l|}{ Indispensable (+semi-) } \\
\hline Arg & 9.5 & 8.8 & 8.6 & 9.5 & 10.0 & 9.8 \\
\hline Cys & 4.3 & 4.0 & 3.9 & 4.3 & 4.4 & 4.3 \\
\hline Ilis & 4.0 & 3.7 & 3.4 & 3.9 & 4.3 & 4.3 \\
\hline lle & 5.9 & 5.4 & 5.1 & 5.6 & 6.5 & 5.9 \\
\hline Leu & 12.2 & 11.3 & 10.7 & 11.3 & 13.1 & 12.1 \\
\hline Lys & 4.7 & 4.5 & 4.3 & 5.0 & 4.6 & 4.6 \\
\hline Met & 3.1 & 2.9 & 2.9 & 2.9 & 3.2 & 3.0 \\
\hline Phe & 8.6 & 7.7 & 7.4 & 7.5 & 8.7 & 8.2 \\
\hline Thr & 5.4 & 5.1 & 4.8 & 5.2 & 5.4 & 5.3 \\
\hline Trp & 2.0 & 2.1 & 2.2 & 2.1 & 2.0 & 2.1 \\
\hline Tyr & 3.6 & 3.3 & 3.0 & 2.8 & 4.1 & 3.1 \\
\hline Val & 7.5 & 6.9 & 6.6 & 7.1 & 7.8 & 7.3 \\
\hline \multicolumn{7}{|l|}{ Dispensable } \\
\hline $\mathrm{Ala}$ & 6.1 & 5.7 & 5.6 & 5.9 & 6.5 & 6.2 \\
\hline Asp & 9.1 & 8.6 & 8.6 & 9.3 & 9.8 & 9.6 \\
\hline Glu & 62.4 & 56.6 & 54.5 & 55.1 & 65.6 & 63.7 \\
\hline Gly & 7.2 & 6.6 & 6.5 & 6.9 & 6.9 & 7.3 \\
\hline Pro & 20.6 & 18.6 & 18.5 & 18.4 & 20.9 & 21.1 \\
\hline Ser & 8.6 & 8.0 & 7.6 & 8.0 & 8.9 & 8.8 \\
\hline
\end{tabular}

' dry matter basis

2 refer to footnote ! to Table 1

solution, 70 to $80 \%$ aqueous ethanol and diluted acid or alkaline solutions, respectively. As was reviewed by Simmonds (1989), storage proteins of wheat, which make up about $720 \mathrm{~g} \mathrm{~kg}^{-1}$ of the total protein, are primarily prolamins and glutenins which are located in the endosperm fraction and are referred to as endosperm proteins. The remaining proteins are metabolically active cytoplasmic proteins, i.e., albumins and globulins. These proteins comprise enzymes, membrane, ribosomal, and other regulatory proteins, as well as some structural proteins (cell wall). These proteins are distributed in the aleurone layer, the pericarp and embryo tis- 
sues, and account for 160,40 and $80 \mathrm{~g} \mathrm{~kg}^{-1}$ of the total protein of wheat, respectively. In this context, it should be mentioned that AA contents and composition in wheat are dependent on the contents and relative proportions of these four protein fractions, since there are large differences in AA composition between these protein fractions (Lásztity, 1983; Simmonds, 1989). For example, the contents of lysine and thrconine ( $100 \mathrm{~g}^{-1} \mathrm{CP}$ ) are much higher in albumins and globulins than in glutenins and prolamins. The opposite is true for the contents of glutamic acid and proline (e.g., Simmonds, 1989).

The content of each of the AA usually increased correspondingly as the CP content increased among the wheat samples (Table 2). Wyatt (1993), in studies with 48 Canadian hard red spring and 47 American wheat samples, observed strong positive linear relationships between the contents of $\mathrm{CP}$ and $\mathrm{AA}$ and concluded that the AA contents in wheat can be reliably predicted from their $\mathrm{CP}$ content. In this study, there was little variation in CP content among the wheat samples. Although the $\mathrm{CP}$ content only increased by 2.9 percentage units from the lowest (W3, $170 \mathrm{~g} \mathrm{~kg}^{-1}$ ) to the highest (W5, $199 \mathrm{~g} \mathrm{~kg}^{-1}$ ) protein wheat sample, the contents of all AA increased correspondingly (Table 2). Because of the small difference in $\mathrm{CP}$ content, the variation in AA content among these wheat samples was also small.

The apparent ileal digestibility values of dry matter in the experimental diets and $\mathrm{CP}$ and $\mathrm{AA}$ in the wheat samples are presented in Table 4 . There were differences $(\mathrm{P}<0.05)$ in the ileal digestibility values of $\mathrm{CP}$ and all $\mathrm{AA}$ among the wheat samples. The digestibility of $\mathrm{CP}$ ranged from 74.7 to $80.5 \%$. Of the indispensable (+semi-) AA, the differences in digestibility values ranged from 4.7 (isoleucine, phenylalanine and tyrosine) to 11.3 (lysine) percentage units. Of the dispensable AA, the differences ranged from 2.6 (glutamic acid) to 12.0 (glycine) percentage units. The apparent ileal digestibility values of AA in the wheat samples used in this study fall within the range of values summarized by Sauer and Ozimek (1986). However, much more variation in the digestibility values of AA in wheat has been reported in the literature. For instance, as was summarized by Sauer and Ozimek (1986), the digestibility values of lysine and threonine ranged from 62.3 to $81.0 \%$ and 61.9 to $78.4 \%$, respectively, whereas these ranged from 59.0 to $70.3 \%$ and 64.2 to $73.0 \%$, respectively in this study. Other factors including fineness of grinding and methodological approaches, which were previously discussed by Sauer and Ozimek (1986), Fan et al. (1994) and Fan and Sauer (1995), were likely responsible for the additional variation in AA digestibility values among the wheat samples reported in the literature.

In agreement with studies by Ivan and Farrell (1976), Sauer et al. (1981) and Green et al. (1987), the apparent ileal digestibility values of glycine, lysine and threonine were relatively low while those of glutamic acid, phenylalanine and proline were relatively high among the AA in wheat (Table 4). The low digestibility values of lysine and threonine and high digestibility values of glutamic 
TABLE 4

The apparent ileal digestibilitiy values of crude protein and amino acids in the wheat samples, $\%$

\begin{tabular}{|c|c|c|c|c|c|c|c|}
\hline & \multicolumn{6}{|c|}{ Wheat samples } & \multirow[b]{2}{*}{$\mathrm{SE}^{2}$} \\
\hline & W1 & W2 & W3 & W4 & WS & W6 & \\
\hline No. of observations & 6 & 4 & 6 & 6 & 5 & 6 & \\
\hline Dry matter ${ }^{3}$ & $74.9^{4}$ & $67.7^{\mathrm{cd}}$ & $69.4^{c}$ & $72.6^{\mathrm{b}}$ & $75.1^{3}$ & $66.1^{d}$ & 0.67 \\
\hline Crude protein & $80.5^{\mathrm{a}}$ & $78.0^{\mathrm{sh}}$ & $76.9^{\mathrm{hc}}$ & $79.4^{a b}$ & $80.1^{\mathrm{ab}}$ & $74.7^{\circ}$ & 1.12 \\
\hline \multicolumn{8}{|c|}{$\begin{array}{l}\text { Amino acids } \\
\text { Indispensable (+semi-) }\end{array}$} \\
\hline Arg & $80.0^{\mathrm{a}}$ & $82.2^{a}$ & $82.6^{a}$ & $81.8^{\mathrm{a}}$ & $81.4^{\circ}$ & $77.5^{b}$ & 2.03 \\
\hline Cys & $79.4^{\mathrm{a}}$ & $76.0^{\mathrm{a}}$ & $78.5^{a}$ & $76.9^{\mathrm{a}}$ & $79.8^{\mathrm{a}}$ & $70.3^{b}$ & 1.41 \\
\hline His & $83.8^{a}$ & $79.8^{\prime}$ & $82.9^{a}$ & $80.5^{a}$ & $81.6^{\mathrm{a}}$ & $74.0^{\mathrm{b}}$ & 1.48 \\
\hline lle & $83.0^{a}$ & $80.1^{\mathrm{c}}$ & $81.6^{\mathrm{ab}}$ & $81.7^{\mathrm{ab}}$ & $80.3^{b c}$ & $78.3^{c}$ & 0.82 \\
\hline Leu & $84.8^{a}$ & $81.4^{c}$ & $83.4^{\mathrm{b}}$ & $83.4^{\mathrm{b}}$ & $82.1^{\mathrm{bc}}$ & $79.9^{c}$ & 0.79 \\
\hline Lys & $70.3^{a}$ & $64.0^{c}$ & $67.5^{\mathrm{ab}}$ & $65.0^{b}$ & $69.4^{\mathrm{ub}}$ & $59.0^{\mathrm{c}}$ & 1.66 \\
\hline Met & $83.4^{n}$ & $78.6^{\mathrm{bc}}$ & $81.0^{\mathrm{b}}$ & $81.1^{\mathrm{b}}$ & $81.2^{b}$ & $76.2^{\circ}$ & 0.84 \\
\hline Phe & $87.5^{\circ}$ & $83.5^{\mathrm{b}}$ & $86.4^{\mathrm{a}}$ & $86.6^{\mathrm{a}}$ & $85.3^{\text {nk }}$ & $82.8^{b}$ & 0.72 \\
\hline Thr & $73.0^{a}$ & $68.7^{\mathrm{ath}}$ & $69.9^{a}$ & $68.8^{\mathrm{ab}}$ & $71.8^{a}$ & $64.2^{b}$ & 1.53 \\
\hline $\operatorname{Trp}$ & $79.5^{a}$ & $75.4^{b}$ & $76.7^{\mathrm{bc}}$ & $77.6^{\mathrm{abc}}$ & $79.3^{\mathrm{ac}}$ & $71.9^{\mathrm{d}}$ & 0.89 \\
\hline Tyr & 77.0 & 73.2 & 76.2 & 77.9 & 74.2 & 73.7 & 1.68 \\
\hline Val & $79.5^{i}$ & $75.1^{\mathrm{bc}}$ & $77.0^{\mathrm{ab}}$ & $76.8^{\mathrm{sb}}$ & $76.9^{\mathrm{sh}}$ & $72.6^{\circ}$ & 1.02 \\
\hline \multicolumn{8}{|l|}{ Dispensable } \\
\hline Ala & $74.8^{:}$ & $70.8^{: \mathrm{b}}$ & $72.0^{\mathrm{ibb}}$ & $70.7^{\mathrm{b}}$ & $71.1^{\text {st }}$ & $65.7^{\circ}$ & 1.29 \\
\hline Asp & $73.9^{\mathrm{a}}$ & $70.6^{\mathrm{ah}}$ & $71.7^{\mathrm{ab}}$ & $69.2^{\mathrm{b}}$ & $71.7^{\mathrm{ab}}$ & $64.8^{\circ}$ & 1.30 \\
\hline Glu & $92.4^{i}$ & $89.9^{\mathrm{bc}}$ & $91.7^{\mathrm{ab}}$ & $92.5^{a}$ & $89.3^{\circ}$ & $89.9^{\mathrm{r}}$ & 0.61 \\
\hline Gly & $74.2^{\mathrm{s}}$ & $67.8^{\mathrm{hx}}$ & $67.8^{\mathrm{bc}}$ & $68.0^{\mathrm{b}}$ & $69.7^{\mathrm{ab}}$ & $62.2^{c}$ & 1.69 \\
\hline Pro & $87.2^{a}$ & $85.5^{\mathrm{ab}}$ & $81.3^{b c}$ & $84.7^{\mathrm{ab}}$ & $82.1^{\text {sth }}$ & $80.4^{b}$ & 2.08 \\
\hline Ser & $83.8^{a}$ & $80.6^{4}$ & $82.3^{a}$ & $81.8^{a}$ & $81.4^{a}$ & $78.2^{\mathrm{b}}$ & 0.96 \\
\hline
\end{tabular}

1 refer to footnote 1 to Table 1

${ }^{2}$ standard crror of the least square mean $(n=6)$

${ }^{3}$ digestibility values of the experimental diets

a.b.c,d means in the same row followed by different letters differ at $\mathrm{P}<0.05$

acid and proline likely resulted from differences in the distribution of these AA among the protein fractions in wheat. As was discussed previously, the contents of lysine and threonine are very low in glutenins and prolamins and high in albumins and globulins and vice versa for the contents of glutamic acid and proline. Furthermore, the albumin plus globulin fractions are distributed in the aleurone layer of wheat (Simmonds, 1989). This layer has thick cell walls, and the proteins are tightly bound to the cellulosic matrix of the aleurone cells limiting their access to proteolytic enzymes of the gastrointestinal tract (Saunders 
and Kohler, 1972). Therefore, it is most likely that proteins and AA "locked-up" inside the aleurone cell walls are of low digestibility, whereas the storage proteins in endosperm are of high digestibility. Saunders et al. (1969) reported that aleurone cells in wheat are largely unbroken during digestion by young chickens. Studies with rats showed that the true protein digestibility values in wheat bran (derived primarily from the aleurone layer and pericarp) and white flour (primarily from endosperm) ranged from 63 to $73 \%$ and from 93 to $96 \%$, respectively (Simmonds, 1989). Furthermore, the low apparent ileal digestibility of threonine and glycine may also, in part, result from their relatively high concentrations in endogenous protein recovered from the distal ileum (e.g., Holmes et al., 1974; Sauer et al., 1977).

Pearson partial correlation analysis was conducted to identify possible inherent factors responsible for the variability of apparent ileal digestibility values of AA among the wheat samples. With the exception of arginine, glutamic acid, proline and tyrosine, the apparent ileal digestibility values of $\mathrm{CP}$ and $\mathrm{AA}$ were negatively correlated $(\mathrm{P}<0.05)$ with the NDF content in the wheat samples (Table 5). These results tend to suggest that differences in NDF content are, in part, responsible for the variation in digestibility values of $\mathrm{CP}$ and most $\mathrm{AA}$ among the samples. A negative relationship between protein digestibility and crude fibre content in cereal grains was also previously reported in studies with pigs and rats (Eggum and Beames, 1983). As was reviewed by Simmonds (1989), an average of $200 \mathrm{~g} \mathrm{~kg}^{-1}$ of the total wheat protein, mainly albumin and globulin, is deposited in the aleurone layer, the pericarp and the seed coat. These fractions make up wheat bran after milling. The protein fractions contained in wheat bran are of relatively low digestibility and can be classified into two types. The first type of protein resides inside the thick cellulosic cell walls in the alcurone layer, the second type of protein is tightly bound to the cellulosic matrix of the aleurone cells (Saunders and Kohler, 1972). Therefore, differences in the NDF content among wheat samples may reflect differences in the proportion of these four major protein fractions. Although the fractions were not separated in this study, one can speculate that samples of wheat with a high NDF content are likely to contain relatively larger amounts of albumin and globulin and lower amounts of glutenin and prolamin fractions than samples with a lower NDF content. However, it should be emphasized that the variability of the ileal digestibility values of $\mathrm{CP}$ and $\mathrm{AA}$ in association with the differences in NDF content among the wheat samples is the combined effects of both genotype and growing conditions. Taverner and Farrell (1981) also reported negative correlation between the NDF content and AA digestibility values in wheat. Furthermore, negative correlation between the NDF content and apparent ileal AA digestibility values was also reported in other feedstuffs of plant origin including peas (Gdala et al., 1992; Fan, 1994) and canola meal (Fan et al., 1996). The NDF fraction comprises a 
TABILE 5

Correlation coefficients between apparent ileal digestibility values of crude protein and amino acids and neutral-detergent fibre contents in the wheat samples and dietary levels of crude protein and amino acids

\begin{tabular}{|c|c|c|c|c|}
\hline & \multicolumn{2}{|c|}{ Neutral-detergent fibre content, $\%$} & \multicolumn{2}{|c|}{ Dietary amino acid contents, $\%$} \\
\hline & $r$ & $P$ & $r$ & $\mathrm{p}$ \\
\hline Crude protein & -0.66 & $0.00 \mathrm{I}$ & 0.11 & $0.6 !$ \\
\hline \multicolumn{5}{|l|}{ Amino acids } \\
\hline \multicolumn{5}{|c|}{ Indispensable (+semi-) } \\
\hline Arg & -0.36 & 0.088 & 0.16 & 0.46 \\
\hline Cys & -0.78 & 0.001 & 0.08 & 0.71 \\
\hline His & -0.72 & 0.001 & 0.11 & 0.42 \\
\hline Ile & -0.59 & 0.003 & 0.16 & 0.47 \\
\hline Leu & -0.62 & 0.001 & 0.14 & 0.51 \\
\hline Lys & -0.77 & 0.001 & 0.05 & 0.83 \\
\hline Met & -0.79 & 0.001 & 0.24 & 0.27 \\
\hline Phe & -0.67 & 0.001 & 0.03 & 0.89 \\
\hline Thr & -0.70 & 0.001 & 0.09 & 0.69 \\
\hline $\operatorname{Trp}$ & -0.85 & 0.001 & 0.31 & 0.10 \\
\hline Tyr & -0.27 & 0.212 & 0.17 & 0.43 \\
\hline Val & -0.71 & 0.001 & 0.10 & 0.65 \\
\hline \multicolumn{5}{|l|}{ Dispensable } \\
\hline Ala & -0.68 & 0.001 & 0.16 & 0.46 \\
\hline Asp & -0.71 & 0.001 & 0.33 & 0.12 \\
\hline Glu & -0.30 & 0.160 & 0.13 & 0.44 \\
\hline Gly & -0.69 & 0.001 & 0.05 & 0.81 \\
\hline Pro & -0.29 & 0.178 & 0.09 & 0.68 \\
\hline Ser & -0.65 & 0.001 & 0.23 & 0.28 \\
\hline
\end{tabular}

' dry matter basis

$r$ - Pearson partial correlation cocficients $(n=33)$

$\mathrm{P}$ - probability of significance level

heterogeneous mixture of structural (cellulose, hemicellulose, and pectins) and non-structural ( $\beta$-glycoside-linked oligosaccharides and lignin) materials (Goering and Van Soest, 1970). Cellulose, hemicellulose, and lignin are water-insoluble, whereas pectins and $\beta$-glycoside-linked oligosaccharides, e.g., $\beta$-glucans, are water-soluble. Several mechanisms by which differences in the NDF content contribute to the variability of apparent ileal AA digestibility values have been proposed. It has been well established that dietary NDF has direct adverse effects on apparent ileal $C P$ and $A \Lambda$ digestibility values in pigs. It was shown that the dietary inclusion of both water-insoluble and soluble fibre depressed the 
apparent ileal digestibility values of CP and AA (Graham et al., 1986; Li et al., 1994; Mosenthin et al., 1994; Schulze et al., 1994; Lenis et al., 1996). The lower ileal digestibility values of $\mathrm{CP}$ and $\mathrm{AA}$ with increasing water-insoluble fibre content may be attributed to an increase in the rate of passage of digesta (Stanogias and Pearce, 1985) and increased distal ileal recoveries of endogenous CP and AA (Sauer et al., 1977; Taverner et al., 1981; De Lange et al., 1989; Furuya and Kaji, 1992; Leterme et al., 1992). On the other hand, the gelling and viscosity properties of water-soluble fibre can decrease the digestion and absorption of nutrients by reducing the mixing of intestinal contents, thus blocking enzymesubstrate interactions. This then forms an unstirred water layer which creates a physical barrier to nutrient absorption (Johnson and Gee, 1981; Anderson et al., 1990). Recently, Huang (1997) in studies with wheat shorts demonstrated that considerable proportions of CP and AA are directly associated with NDF and are of low digestibility. Their results imply that in plant feedstuffs including wheat, significant amounts of CP and AA are associated with NDF in a form that is of low digestibility. Therefore, the higher the NDF content, the lower the ileal digestibility values of $\mathrm{CP}$ and AA.

Fan et al. (1994) showed that the apparent ileal digestibility values of $\mathrm{CP}$ and AA are quadratically affected by dietary $\mathrm{CP}$ and $\mathrm{AA}$ contents unless those $\mathrm{CP}$ and AA contents in assay diets excecd their corresponding 'threshold levels'. Although there were some differences in the dietary levels of $\mathrm{AA}$ among the experimental diets (Table 2), it was surprising to see that Pearson partial correlation analysis revealed no correlation $(P>0.05)$ between dietary AA contents and the corresponding ileal AA digestibility values among the wheat samples (Table 5). The possibility of effects of differences in dietary AA contents on the variability of ileal amino acid digestibility values in these wheat samples was therefore excluded. This was likely due to the fact that, with the exception of the limiting AA (i.e., lysine, threonine and tryptophan), the contents of CP and other $\mathrm{AA}$ in these high-protein wheat samples were very close to, or higher than, the established 'threshold levels' of CP and AA determined with soyabean meal. In addition, different feed ingredients may also differ in values of the "threshold levels' of CP and AA as were previously defined (Fan et al., 1994). On the other hand, our previous study also showed that determination methods had no effects on the determination of apparent ileal $\mathrm{CP}$ and $\mathrm{AA}$ digestibility values in wheat (Fan and Sauer, 1995b). In this study, ileal CP and AA digestibility values in the wheat samples were all measured with the direct method. Therefore, methodological approaches were not responsible for the variability of apparent ileal C.P and AA digestibility values in these high-protein wheat samples.

In conclusion, measured with the ilcal analysis method, there were differences in the apparent ileal digestibility values of all AA among the high-protein wheat samples. Differences in the NDF content among the wheat samples were, 
in part, responsible for the variation, whereas methodological approaches were not the sources of the variation. Furthermore, the relatively low digestibility values of lysine, threonine and tryptophan further accentuate the limitation of these AA in proteins from wheat.

\section{ACKNOWLEDGEMENTS}

The authors are very grateful to B. Tchir and C. Gorsak for their assistance with animal surgery and to R. Van Weelden, R. McDaniel, M. Phelps, G. Francisco and K. Schuchart (Heartland Lysine Inc., Chicago, IL) for the analyses of amino acids.

\section{REFERENCES}

Anderson J.W., Deakins D.A., Floore T.L., Smith B.M., Whitis S.E., 1990. Dietary fiber and coronary heart discase. Food Sci. Nutr. 29, 95-147

AOAC, 1990. Official Methods of Analysis of the Association of Official Analytical Chemists. $15^{\text {th }}$ Edition. Washington, DC

Byers M., Kirkman M.A., Miflin B.J.. 1978. Plant Proteins: Factors affecting the quality and yield of seed protein. G. Norton, G. Butterworths (Editors). London (UK), pp. 227-243

CCAC, 1980. Canadian Council on Animal Care: Guide to the Care and Use of Experimental Animals. Vol. 1 (with addendum). Ottawa (Canada)

De Lange C.F.M., Sauer W.C., Mosenthin R., Souffrant W.B., 1989. The effect of feeding different protein-free diets on the recovery and amino acid composition of endogenous protein collected from the distal ileum and feces in pigs. J. Anim. Sci. 67, 746-754

Draper N.R., Smith H., 1981. Applied regression analysis: The use of „Dummy” variables in multiple regression. $2^{\text {ud }}$ Edition. N.R. Draper, H. Smith (Editors). John Wiley \& Sons Inc., New York, pp. 241-257

Eggum B.O., Beames R.M., 1983. Seed Proteins - Biochemistry, Genetics, Nutritive Values: The Nutritive Value of Seed Proteins. W. Gottschalk and H.P. Müller, H. P. Matinus Nijhoff Dr. W. Junk Publishers (The Netherlands), pp. 499-531

Fan M.Z., 1994. Methodological considerations for the determination of amino acid digestibility in pigs. Ph.D. Dissertation, University of Alberta (Canada)

Fan M.Z., Saucr W.C., 1995a. Determination of apparent ileal amino acid digestibility in barley and canola meal for pigs with the direct, difference, and regression methods. J. Anim. Sci. 73, 2364 2374

Fan M.Z., Sauer W.C., 1995b. Determination of apparent ileal amino acid digestibility in peas for pigs with the direct, difference, and regression methods. Livest. Prod. Sci. 44, 61-72

Fan M.Z., Sauer W.C., Gabert V.M., 1996. Variability of apparent ileal amino acid digestibility in canola meal for growing-finishing pigs. Can. J. Anim. Sci. 76, 563-569

Fan M.Z., Sauer W.C., Hardin R.T., Lien K.A., 1994. Determination of apparent ileal amino acid digestibility in pigs: effect of dietary amino acid level. J. Anim. Sci. 72, 2851-2859 
Fenton T.W., Fenton M., 1979. An improved procedure for determination of chromic oxide in feed and feces. Can. J. Anim. Sci. 59, 631-634

Furuya S., Kaji Y., 1992. The effect of feed intake and purified cellulose on the endogenous iteal amino acid flow in growing pigs. Brit. J. Nutr. 68, 463-472

Gdala J., Buraczewska L., Grala W., 1992. The chemical composition of different types and varieties of pea and the digestion of their protein in pigs. J. Anim. Feed Sci. 1, 71-79

Goering H.K., Van Soest P.J., 1970. Agriculture Handbook: Forage Fiber Analysis (Apparatus, Reagents. Procedures and Some Application). Number 379. ARS, USDA, Washington, DC

Graham H., Hesselman K. Aman P., 1986. The influence of wheat bran and sugar-beet pulp on the digestibility of dietary components in a cereal-based pig diet. J. Nutr. 116, 242-251

Green S., Bertrand S.L., Madeleine J., Duron C., Maillard R.A., 1987. Digestibility of amino acids in maize, wheat and barley meal, measured in pigs with ileo-rectal anastomosis and isolation of the large intestine. J. Sci. Food Agr. 41, 29-43

Holmes J.H.G., Bayley H.S., Leadbeater P.A., 1974. Digestion of protein in the small and large intestine of the pig. Brit. J. Nutr. 32, 479-489

Huang S.X., 1997. The Nutritive Value of Micronized Cereal Grains and Wheat Shorts for Pigs, $\mathrm{Ph}$.D. Dissertation: Ileal digestibilities of neutral-detergent fiber, crude protein and amino acids associated with neutral-detergent fiber in wheat fractions fed to growing pigs. University of Alberta, Edmonton (Canada), pp. 89-105

Ivan M., Farrell D.J., 1976. Nutritional evaluation of wheat. 5. Disappcarance of components in digesta of pigs prepared with two re-entrant cannulae. Anim. Prod. 23, 111-119

Johnson I.T., Gee J.M., 1981. Effect of gel-forming gums on the intestinal unstirred water layer and Sugar transport in vitro. Gut 22, 398-404

Jones A.D., Hitchcock C.H.S., Jones G.H., 1981. Determination of tryptophan in feeds and feed ingredients by high-performance liquid cluromatography. Analyst 106, 968-973

Lásztity R., 1983. Proceedings of International Association of Cereal Chemistry Symposium on Amino Acid Composition and Biological Value of Cereal Proteins: Cereal Proteins - Past, Present, and Future. R. Lásztity, M. Hidvégi (Editors), Budapest (Hungary), pp. 3-26

Lenis N.P., Bikker P., Van der Meulen J., Van Diepen J., Bakker J.G.M., Jonbloed A.W., 1996. Effect of dictary neutral detergent fiber on ileal digestibility and portal flux of nitrogen and amino acids and on nitrogen utilization in growing pigs. J. Anim. Sci. 74, 2687-2692

Leterme P., Pirard L., Théwis A., 1992. A note on the effect of wood cellulose lcvel in protein-free diets on the recovery and amino acid composition of endogenous protein collected from the ilcum in pigs. Anim. Prod. 54, 163-165

Li S., Sauer W.C., Hardin R.T., 1994. Effect of fiber on amino acid digestibility in young pigs. Can. J. Anim. Sci. 74, 327-33

Mason V.C., Bech-Andersen S., Rudemo M., 1980. Hydrolysate preparation for anino acid determinations in feed constituents. 8. Studies of oxidation conditions for streamlined procedures. J. Anim. Physiol. Anim. Nutr. 43, 146-164

Mosenthin R., Sauer W.C., Ahrens F., 1994. Dietary pectin's effect on ileal and fecal amino acid digestibility and exocrine pancreatic secretions in growing pigs. J. Nutr. 124, 1224-1229

NRC, 1988. Nutrient Requirements of Swine. $9^{\text {th }}$ Edition. National Academy Press, Washington, DC Osborne R.E., 1918. The Vegetable Proteins. Longmans. Green \& Co, London (UK)

Sauer W.C., 1976. Factors affecting amino acid availabilities for cereal grains and their components for growing monogastric animals. Ph. D. Dissertation. University of Manitoba, Winnipeg (Canada)

Sauer W.C., Jorgensen H., Berzins R.A., 1983. Modified nylon bag technique for determining apparent digestibilities of protein in feedstuffs for pigs. Can. J. Anim. Sci. 63, 233-237 
Sauer W.C., Kennelly J.J., Aherne F.X., Cichon R.M., 1981. Availabilities of amino acids in barley and wheat for growing pigs. Can. J. Anim. Sci 61, 793-802

Sauer W.C., Ozimek L., 1986. Digestibility of amino acids in swine: results and their practical application. A revicw. Livest. Prod. Sci. 15, 367-388

Sauer W.C., Stothers S.C., Parker R. J., 1977. Apparent and true availabilities of amino acids in wheat and milling by-products for growing pigs. Can. J. Anim. Sci. 57, 775-784

Saunders R.H., Kohler G.O., 1972. In vitro determination of protein digestibility in wheat millfeeds for monogastric animals. Cereal Chem. 49, 98-103

Saunders R.H., Walkers H.G., Kohler G.O., 1969. Aleurone cells and the digestibility of wheat millfeeds. Poultry Sci. 48, 1497-1503

SAS, 1988. SAS/STAT ${ }^{(4)}$ User's Guide: Statistics (Release 6.03). SAS Inst. Inc.. Cary. NC

Schulze H., Van Leeuwen P., Verstegen M.W.A., Huisman J., Souffrant W.B., Ahrens F., 1994. Effect of level of dietary neutral detergent fiber on ileal apparent digestibility and ileal nitrogen losses in pigs. J. Anim. Sci. 73, 2362-2368

Simmonds D.H., 1989. Wheat and Wheat Quality in Australia. William Brooks, Queensland (Australia)

Stanogias G., Pearce G.R., 1985. The digestion of fiber by pigs. 1. The effect of amount and type of fiber on apparent digestibility, nitrogen balance and rate of passage. Brit. J. Nutr. 53, 513-530

Steel R.G.D., Torric J.11., 1980. Principles and Procedures of Statistics: A Biometrical Approach. $2^{\text {nd }}$ Edition. McGraw-Hill Book Company, New York

Suleiman A., 1987. 1985 Average Analysis of Albcrta Feeds. Agdex 100/81-5. Alberta Agriculture. Edmonton (Canada)

Tavemer M.R., Farrell D.J., 1981. Availability to pigs of amino acids in cereal grains. 4. Factors influencing the availability of amino acids and energy in grains. Brit. J. Nutr. 46, 18!-192

Taverner M.R., Hume I.D., Farrell D.J., 1981. Availability to pigs of amino acids in cereal grains. I. Endogenous levels of amino acids in ileal digesta and faeces of pigs given cereal diets. Brit. J. Nutr. $46,149-158$

Wyatt C.L., 1993. Washington State University Swine Information Day Proceedings: Balancing swine rations for amino acids: utilizing regression equations to estimate amino acid levels in certain cereal grains. Vol. 8. Washington State University, pp. 60-68

Żcbrowska T., 1973. Digestion and absorption of nitrogenous compounds in the large intestine of pigs. Rocz. Nauk. rol., Ser. B 95, 85-90 


\section{STRESZCZENIF}

\section{Zmienność wartości pozornej strawności jelitowej aminokwasów różnych odmian pszenicy wysoko-bialkowej u rosnących świń}

Celem pracy było zbadanie czynników odpowiedzialnych za zmienność pozornej jelitowej strawności aminokwasów (AA) różnych odmian pszenicy wysoko-białkowej. Sześć wieprzków, o średniej początkowej m.c. $30,5 \mathrm{~kg}, \mathrm{z}$ prostymi T-przetokami do końcowego odcinka jelita biodrowego, żywiono 6 dictami w układzie kwadratu łacińskiego 6 x 6 . Każda z diet zawicrała po $970 \mathrm{~g} \mathrm{~kg}^{-1}$ różnych odmian pszenicy. Jako wskaźnik do oznaczania strawności zastosowano trójtlenek chromu. Wieprzki żywiono dwa razy dziennie, o godz. 8 i 20, dietą wynoszącą $1,600 \mathrm{~g} /$ dzień. Każdy okres doświadczalny wynosil 8 dni.

Stwierdzono istotne $(P<0,05)$ różnice w strawności wszystkich AA pomiędzy odmianami pszcnicy. Spośród niezbędnych (+ częściowo) AA, w obrębie każdej próby, współczynniki strawności lizyny i treoniny, pierwszego i drugiego ograniczającego AA, były mniejsze i wahały się od 59,0 do $70,3 \%(P<0,05)$ oraz od 64,2 do $73, \%(P<0,05)$, odpowiednio. Z wyjątkicm argininy i tyrozyny, współczynniki strawności pozostałych niezbędnych (+ częściowo-) AA, były ujemnie skorelowane $(\mathrm{P}<0,05)$ z zawartością NDF, podczas gdy różnice w zawartości AA w dietach nie wpłynçły na zmicnność współczynników strawności jelitowej AA badanych odmian pszenicy.

W podsumowaniu stwierdzono, że w oparciu o analityczne metody pomiaru w jelicie biodrowym współczynniki strawności AA różnych odmian pszenicy wysoko-białkowej znacznic sį̨ różnily. Zmienność ta spowodowana byla $w$ dużej micrze różną zawartością NDF. Stosunkowo niska strawność lizyny, treoniny i tryptofanu wskazuje dodatkowo na niedobór tych AA w białku pszenicy. 